\title{
Human-Induced Soil Degradation in the Kitakami Mountains, Northeast Japan
}

\author{
Celia Yoshimi Takachi*1 and Katsuhiro Inoue*2
}

\begin{abstract}
There is a large degraded area of about 350 ha on the ridge portion of the Kitakami mountains, especially on the windward, west-facing slope. The area has volcanic ash overlying an angular gravel layer. The soils in the area are formed of Holocene tephras, Iwate-b from Iwate volcano and Chuseri pumice from Towada volcano and Pleistocene tephras, Akita-Komagatake-g and Yanagisawa pumice, from AkitaKomagatake volcano. The degradation phenomenon is believed to have been triggered by the felling of the native beech (Fagus crenata) forest to create grassland initially for the breeding of horses and later on cattle followed by bad pasture management or mere abandonment of the land. Removal of the native forest exposes the unprotected soil to the severe periglacial environment. The exposed soil is then subjected to repeated freezing and thawing during winter which promotes wind erosion and rain out-wash. The degradation process is also enhanced by the unique properties of weathered tephric materials such as high allophane content. The ${ }^{14} \mathrm{C}$ dating of the buried A horizon shows that degradation phenomenon started from around the Edo $(270 \pm 80$ yrs BP) to the Meiji $(100 \pm 70$ yrs BP) eras. Development of the degradation phenomenon in the Kitakami mountains is a result of a chain of events. After the felling of the native forest to create grasslands, the severe environmental conditions coupled with mismanagement, gave rise to the formation of the bare lands. The degradation phenomenon in the Kitakami mountains also shows the influence of the interaction between climate, topography and human activity.
\end{abstract}

Key Words : deforestation, soil degradation, soil erosion, volcanic ash soil, Kitakami mountains

\section{Introduction}

Soil erosion is caused by a combination of many factors (natural and/or anthropogenic) and is the most serious form of soil degradation because it can not be reversed. According to Brown (1981), the world now loses some 23 billion tons of topsoil per year from uplands in excess of new soil formation.

In Japan, pasturing had been done solely on the lowland areas but during the Edo and Meiji eras, the highlands were also used to initially feed horses of the shogunate and latter on cattle. In the highlands, clearing of the native forests, their replacement by grasslands and bad pasture management are believed to be the sequence of events that led to the development of the bare lands. In many regions such as the Sahel and Indian subcontinents, dramatic increases in animal population and uncontrolled and excessive grazing have been noted to be responsible for depleting vegetation, hard set-

Received October 9, 1998. Accepted May 29, 1999.

*1 Laboratory of Environmental Soil Science, Obihiro University of Agriculture and Veterinary Medicine. Obihiro, Hokkaido, 080-8555, Japan.

*2 Faculty of Agriculture, Iwate University. 3-18-8 Ueda, Morioka, 020-8550, Japan (Deceased August 16, 1998). 


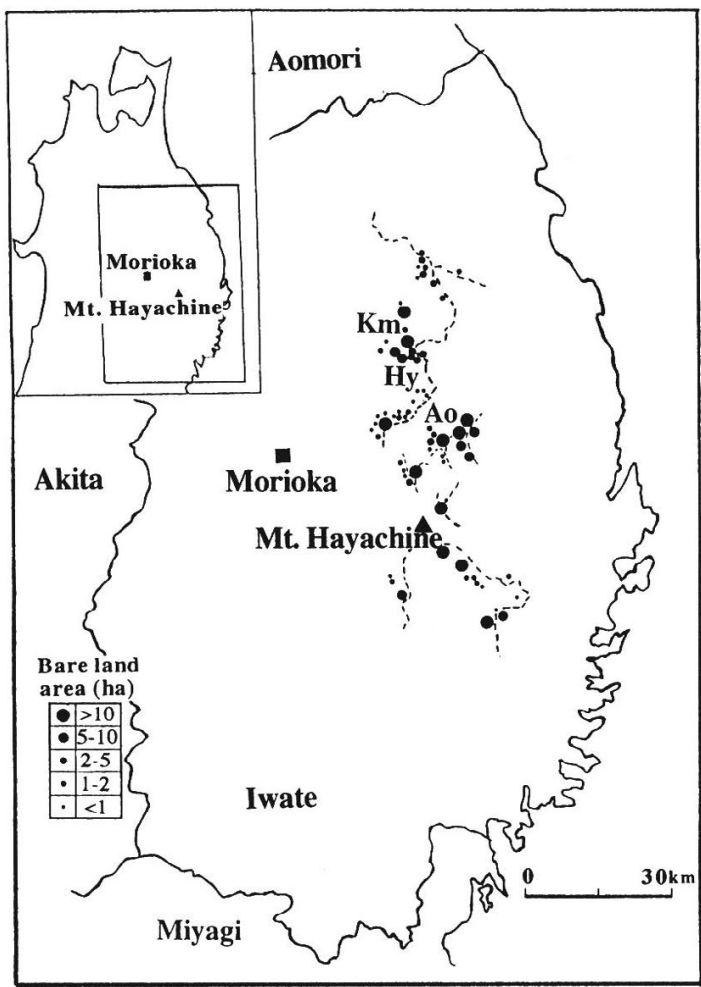

Fig. 1 Map showing sampling localities and distribution of bare land areas in the Kitakami mountains

Dotted lines represent the chain of peaks of the mountains. After Takahashi (1976). ting and accelerating run-off and erosion (Lal and Stewart, 1992).

There is a peneplain on the Kitakami mountains in the Tohoku district of Japan (Fig. 1). It is located at an elevation of about $800 \mathrm{~m}$ a.s.l. and covers an area of about 70,000 ha. There are about 350 ha of bare lands on the peneplain (Suiri Kagaku Kenkyujo, 1996) (Fig. 2).

The degradation phenomenon on the Kitakami mountains has attracted the attention of many researchers. Studies relating to geomorphology, degradation-control and mechanism of the denudation of the Kitakami mountains have been conducted (Higaki, 1988, 1992 ; Koaze and Sawaguchi, 1988 ; Suiri Kagaku Kenkyujo, 1996). Although these studies have reported degradation phenomenon has existed for a long time, its beginning and mechanism of development are not clear. Thus, the objectives of this study are to determine the inception and mechanisms of the degradation phenomenon.

\section{Outline of the studied area}

The study area is located on the ridge portion of the Kitakami mountains, northeast Japan. The area includes 350 ha of bare lands. Three areas located at the central part of the mountains which show the degradation phenomenon were selected. The three areas are ;

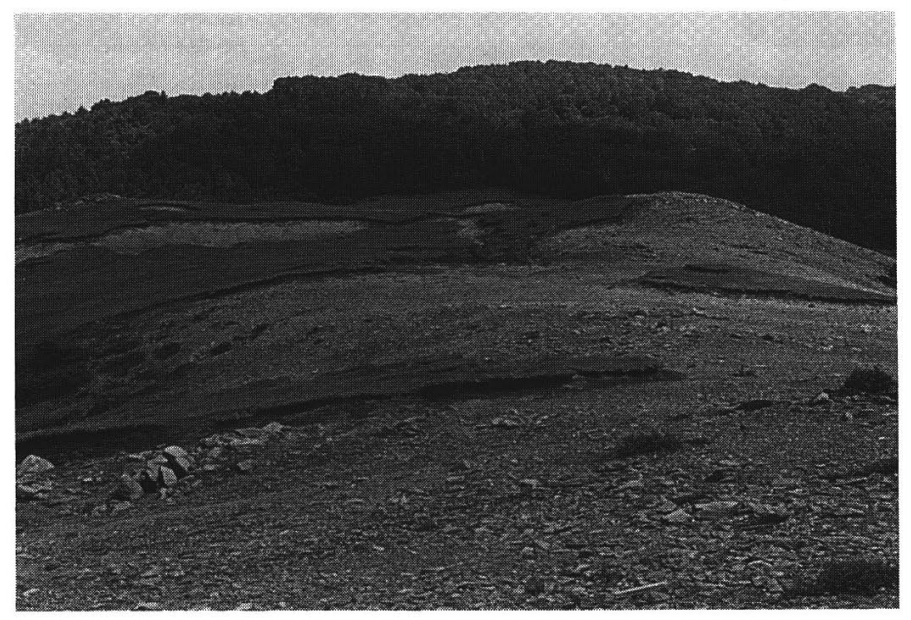

Fig. 2 View of Kamisodegawa sampling area

Note the native beech forest in the background and the grassland with bare land development in the foreground. 
Kamisodegawa in Kuzumaki town, Hayasaka in Hayasaka Pass and Aomatsusawa in Iwaizumi town.

The vegetation on the ridge of the Kitakami mountains is basically made up of natural forests, reforested areas and grasslands. According to a document by Suiri Kagaku Kenkyujo (1996), more than half of the Kitakami mountains is covered by deciduous broad leaf beech (Fagus crenata) forest. The grassland areas are the places that have been mainly affected by the degradation phenomenon. Iwata (197.1) classified the main vegetation types on the Kitakami mountains into natural vegetation and secondary vegetation.

The dominant plants growing at the study area are $F$. crenata in the native forest, Betula ermanii in the secondary forest and Calamagrostis hakonensis and Brachypodium sylvaticum in the grasslands (Table 1).

Bare lands were observed in the grassland areas, especially, at feeding and watering lots where cattle usually congregate and also on their tracks. In the areas covered by secondary forest with grass undergrowth, no bare lands were observed. The forest trees might have protected the soils from wind-erosion and low temperature and thus prevented the development of bare lands in the forested areas. According to Suiri Kagaku Kenkyujo (1996), the possibility of a bare land developing in the forested area is almost nil.

The study areas have about a $1 \mathrm{~m}$ thick of Holocene and Pleistocene volcanic ash layer overlying an angular gravel substratum. According to Koaze and Sawaguchi (1988), there is no volcanic ash dating on the Last Glacial age because during that period the surface soil was removed by either massive movement down to lower slope or by wind erosion. It might have been exposed previously during the Last Glacial age when the surface soil was removed.

\section{Origin of bare lands}

The native deciduous beech forest area on the ridge (above $800 \mathrm{~m}$ a.s.l.) of the Kitakami mountains, was converted to grassland in the 18 th century. Initially, it was used to feed horses for the shogunate and, later on, cattle. To create the grassland, the native beech forest was felled, thinned and replaced by grassland
Table 1 Local characteristics of the sampling sites

\begin{tabular}{|c|c|c|c|}
\hline $\begin{array}{l}\text { Depth } \\
(\mathrm{cm})\end{array}$ & Horizons & $\begin{array}{c}\begin{array}{c}\text { Soil color } \\
\text { (moist) }\end{array} \\
\end{array}$ & Present dominant vegetation \\
\hline \multicolumn{4}{|c|}{ Kamisodegawa, Kuzumaki (1,026 m a.s.l.) } \\
\hline \multicolumn{4}{|l|}{ Forest } \\
\hline $0-10$ & A & 10YR $1.7 / 1$ & Fagus crenata Blume \\
\hline $10-20$ & A2 & $10 \mathrm{YR} 2 / 2$ & Sasa sp \\
\hline $20-28$ & $\mathrm{AB}$ & $10 \mathrm{YR} 2 / 3$ & \\
\hline $28-50$ & B & $10 \mathrm{YR} 3 / 4$ & \\
\hline $50-53$ & $2 \mathrm{C}$ & $10 \mathrm{YR} 5 / 6$ & \\
\hline $53-76$ & $2 \mathrm{~B}$ & $10 \mathrm{YR} 4 / 5$ & \\
\hline $76-110$ & $2 \mathrm{BC}$ & $5 Y 4 / 2-2.5 Y 5 / 2 *$ & \\
\hline \multicolumn{4}{|l|}{ Grassland } \\
\hline $0-7$ & A & $10 Y R 2 / 3$ & Calamagrostis hakonensis Franch. et Sav. \\
\hline $7-15$ & B & $10 Y R 3 / 4$ & Brachypodium sylvaticum Huds. \\
\hline $15-20$ & $2 \mathrm{~A}$ & 10YR1.7/1 & Zoysia japonica Steudel \\
\hline 20-35 & $2 \mathrm{~A} 2$ & $10 \mathrm{YR} 2 / 1$ & \\
\hline $35-50$ & $2 \mathrm{~B}$ & $10 Y R 2 / 2$ & \\
\hline $50-55$ & $3 \mathrm{C}$ & $10 Y R 5 / 8$ & \\
\hline $55-75$ & $4 \mathrm{~A}$ & $10 Y R 3 / 4$ & \\
\hline $75-100$ & $4 \mathrm{AC}$ & $10 Y R 4 / 6$ & \\
\hline $100 \sim$ & $4 \mathrm{C}$ & $10 \mathrm{YR} 5 / 7$ & \\
\hline \multicolumn{4}{|l|}{ Bare land } \\
\hline $0-4$ & B & $10 Y R 3 / 3$ & \\
\hline $4-14$ & $\mathrm{BC}$ & $10 \mathrm{YR} 4 / 5$ & \\
\hline 14 & $\mathrm{C}$ & $2.5 Y 5 / 3$ & \\
\hline \multicolumn{4}{|c|}{ Aomatsusawa, Iwaizumi (1,149 $\mathrm{m}$ a.s.l.) } \\
\hline \multicolumn{4}{|c|}{ Grassland } \\
\hline $0-20$ & B & 10YR3/4 & Calamagrostis hakonensis Franch. et Sav. \\
\hline $20-23$ & $2 \mathrm{~A}$ & 10YR $1 / 1$ & Brachypodium sylvaticum Huds. \\
\hline $23-33$ & $2 \mathrm{~B}$ & $10 \mathrm{YR} 2 / 3$ & Zoysia japonica Steudel \\
\hline $33-45$ & $2 \mathrm{BC}$ & $10 \mathrm{YR} 3 / 3$ & \\
\hline $45-50$ & $3 \mathrm{C}$ & 10YR5/6 & \\
\hline $50-90$ & $4 \mathrm{BC}$ & $10 \mathrm{YR} 4 / 6$ & \\
\hline 90 & $4 \mathrm{C}$ & - & \\
\hline \multicolumn{4}{|c|}{ Secondary Forest } \\
\hline $0-4$ & A & $10 \mathrm{YR} 2 / 2$ & Betula ermanii Cham. \\
\hline 48 & $2 \mathrm{~A}$ & $10 \mathrm{YR} 1 / 1$ & \\
\hline 8-16 & $2 \mathrm{~B}$ & $10 \mathrm{YR} 2 / 3$ & \\
\hline $16-28$ & $2 \mathrm{BC}$ & $10 \mathrm{YR} 4 / 4$ & \\
\hline $28-78$ & $3 \mathrm{BC}$ & $10 Y R 4 / 6$ & \\
\hline \multicolumn{4}{|l|}{ Bare land } \\
\hline $0-38$ & $\mathrm{C}$ & $10 Y R 4 / 6$ & \\
\hline \multicolumn{4}{|c|}{ Hayasaka, Hayasaka Pass (1,118 $\mathrm{m}$ a.s.l. $)$} \\
\hline \multicolumn{4}{|l|}{ Forest } \\
\hline $0-12$ & A & $7.5 \mathrm{YR} 2 / 1$ & Fagus crenata Blume \\
\hline $12-21$ & $\mathrm{AB}$ & $7.5 Y R 2 / 2$ & Tilia japonica Simk. \\
\hline $21-42$ & B & $7.5 \mathrm{YR} 2 / 3$ & Carex dolichostachya Hayata var. \\
\hline $42-83$ & $2 \mathrm{~B}$ & $7.5 Y R 3 / 4$ & glaberrima T. Koyama \\
\hline 83-103 & $2 \mathrm{BC}$ & $7.5 Y R 4 / 6$ & Sasa sp \\
\hline \multicolumn{4}{|l|}{ Grassland } \\
\hline $0-15$ & A & 10YR3/3 & Calamagrostis hakonensis Franch. et Sav \\
\hline $15-22$ & $2 \mathrm{~A}$ & 10YR $2 / 1$ & Brachypodium sylvaticum Huds. \\
\hline $22-33$ & $2 \mathrm{AB}$ & $10 \mathrm{YR} 2 / 3$ & Spiraea nipponica Maxim. form. \\
\hline $33-48$ & $2 \mathrm{~B}$ & $10 Y R 3 / 4$ & rotundifolia Makino \\
\hline $48-97$ & $4 \mathrm{BC}$ & $10 Y R 4 / 4$ & Zoysia japonica Steudel \\
\hline \multicolumn{4}{|c|}{ Secondary Forest } \\
\hline $0-4$ & A & $7.5 \mathrm{YR} 2 / 2$ & Betula ermanii Cham. \\
\hline $4-9$ & $\mathrm{AB}$ & $7.5 \mathrm{YR} 2 / 3$ & Sasa $\mathrm{sp}$ \\
\hline $9-17$ & $2 \mathrm{~A}$ & $7.5 \mathrm{YR} 2 / 1$ & \\
\hline $17-33$ & $2 \mathrm{~B}$ & $7.5 Y R 2 / 2$ & \\
\hline $33-63$ & $3 \mathrm{C}$ & $7.5 Y R 3 / 4$ & \\
\hline $63 \sim$ & $4 \mathrm{BC}$ & $10 \mathrm{YR} 4 / 4$ & \\
\hline \multicolumn{4}{|l|}{ Bare land } \\
\hline $0-4$ & B & 10YR4/6 & \\
\hline $4-12$ & $\mathrm{C}$ & $10 \mathrm{YR} 4 / 6$ & \\
\hline
\end{tabular}


species. Bad pasture management such as high livestock density and bad troughs distribution, or mere abandonment of the land is thought to be the beginning of the bare land development. Towards the end of the Meiji era, the grassland production dropped sharply to about one-tenth of its original rate due to the effect of the trampling of horses and cattle and the death of diseased grasses (Kitada, 1985). Thinning of forests partially to create patches of grasslands within forests has been commonly practiced since olden times. However, overthinning of the forests also led to the development of some bare lands seen in the study areas, although they cover smaller areas.

At the beginning of the Meiji era, the denudation had just begun but during the last 150 years, it has progressed rapidly. The period of rapid denudation coincided with the period of crop failure and hunger in the Tohoku area due to low temperatures caused by a periglacial climate in the middle and high latitudes (Koaze and Sawaguchi, 1988).

From 1970, the Japanese government adopted strict environmental policies to forestall the enlargement of the bare lands and to restore the degraded area. With the cooperation of different institutions (Aomori Forestry Department, Iwaizumi Forestry Office, the Faculty of Agriculture of Iwate University and Tohoku Branch of the Forestry Research Institute), the survey of the degraded area was started. At the beginning, barriers were built to suppress the rapid expansion of the bare land areas, after which reforestation was undertaken. After almost 30 years, some progress has been made. However, some ruined areas. are still present, showing how difficult it is to reverse a degradation process set in motion some two centuries ago.

\section{Meteorological conditions characteris-} tics

Meteorological conditions of the ridge of the Kitakami mountains are very severe due to the prevailing periglacial environment. This area experiences very low temperatures during winter and heavy rainfall during summer.

A rainfall amount of 700 to $800 \mathrm{~mm}$ is concentrated within the period from May to October. However, the period from July to September, known as the typhoon period, experiences the greatest rainfall intensity (Suiri Kagaku Kenkyujo, 1996). It is responsible for the rain outwash of the surface soil in the area.

The north-south orientation of the mountains gives them a wide west and east-facing sides. The study area receives strong wind from the west direction during winter and strongly affects the west-facing, windward slope. The transition from winter to spring in April brings strong winds, although the highest velocity is observed during winter, sometimes reaching $45 \mathrm{~m} / \mathrm{s}$. Onodera (1963) observed that the strong winds in the Ohu mountains of northern Japan, are the cause of the asymmetric nature of trees with their branches bent eastward. He also noticed the degree of asymmetry decreases with increasing plant density. Asymmetrically oriented trees were observed in the study area too. These strong winds are also the reason for low accumulation of snow on the west-facing slope. A thin layer of snow does not shield the soil well enough from wind erosion. Although snowfall in the area is low, temperatures in winter are remarkably low and the annual temperature variation is wide, reaching values lower than $-10^{\circ} \mathrm{C}$ in winter and higher than $30^{\circ} \mathrm{C}$ in summer (Koaze and Sawaguchi, 1988). Soils that are not protected by forest vegetation are directly subjected to the low temperatures, experience frost heaving and are characterized by frost columns. In these soils, freezing up to $50 \mathrm{~cm}$ depth is not rare (Suiri Kagaku Kenkyujo, 1996). Freezing and thawing of the soils greatly contribute to wind erosion. According to Suzuki (1966), the number of freeze-thaw days in the higher mountainous regions of northern Japan is high, being of about 125 days/year. The study area has udic moisture and frigid temperature regimes (Soil Survey Staff, 1992).

\section{Topography}

The Kitakami mountains have a north to south orientation and show a narrow and long spindle shape. Generally, the central portion of the mountains is higher than the northern and southern portions, and sharper slopes occur on the western and eastern sides.

The topography of the ridge is relatively plain, ranging from 600 to $1,300 \mathrm{~m}$ a.s.l. and it is 
believed to have developed into a peneplain (Koaze and Sawaguchi, 1988; Higaki, 1992) during the Quaternary. The western slope is relatively more gentle and convex while the eastern slope is sharper and concave, giving the mountain a characteristic asymmetric shape. This asymmetrical shape is believed to be an effect of the cold west winds which accumulate snow on the east facing slope and which create cornices on that side of the mountains. The windward western slope, on the other hand, with no forest cover and no snow protection is hence directly exposed to low temperature. Consequently, the western slope experiences frost heaving and are also characterized by frost columns and these promote wind-erosion and rain out-wash. Thus, the development of bare lands appears to be concentrated on the west-facing windward slope.

\section{Soil survey}

The degradation phenomenon of soils occurs mainly at the central and northern portions of the Kitakami mountains. The surface soils of these areas are formed from basaltic-andesitic tephra. According to Shoji and Otowa (1988), basaltic-andesitic tephras contain abundant colored glasses which weather easily to supply larger amounts of bases. They stated that these bases prevent soil acidification and Alhumus complex formation, a condition which favors allophane formation.

The soils of the study area were formed from the following tephras; Iwate-b (IW-b : 3,0604,780 yrs BP, basaltic andesite) from Iwate volcano (Inoue and Yoshida, 1980), Chuseri pumice (To-Cu : 5,500 yrs BP, dacitic) from Towada volcano (Machida, 1987), and Akita-Komagatake-g tephra and Yanagisawa pumice (AK-g and YP : 12,350 yrs BP, andesitic) from AkitaKomagatake volcano (Inoue, 1980).

\section{Materials and methods}

Soil samples were collected from 3 areas showing bare land formation; Kamisodegawa, Aomatsusawa and Hayasaka. At each area, soil samples were collected from pedons located in, at least, three of the following : forest (undisturbed), grassland and/or secondary forest (partially disturbed) and bare land (completely disturbed) (Fig. 3).

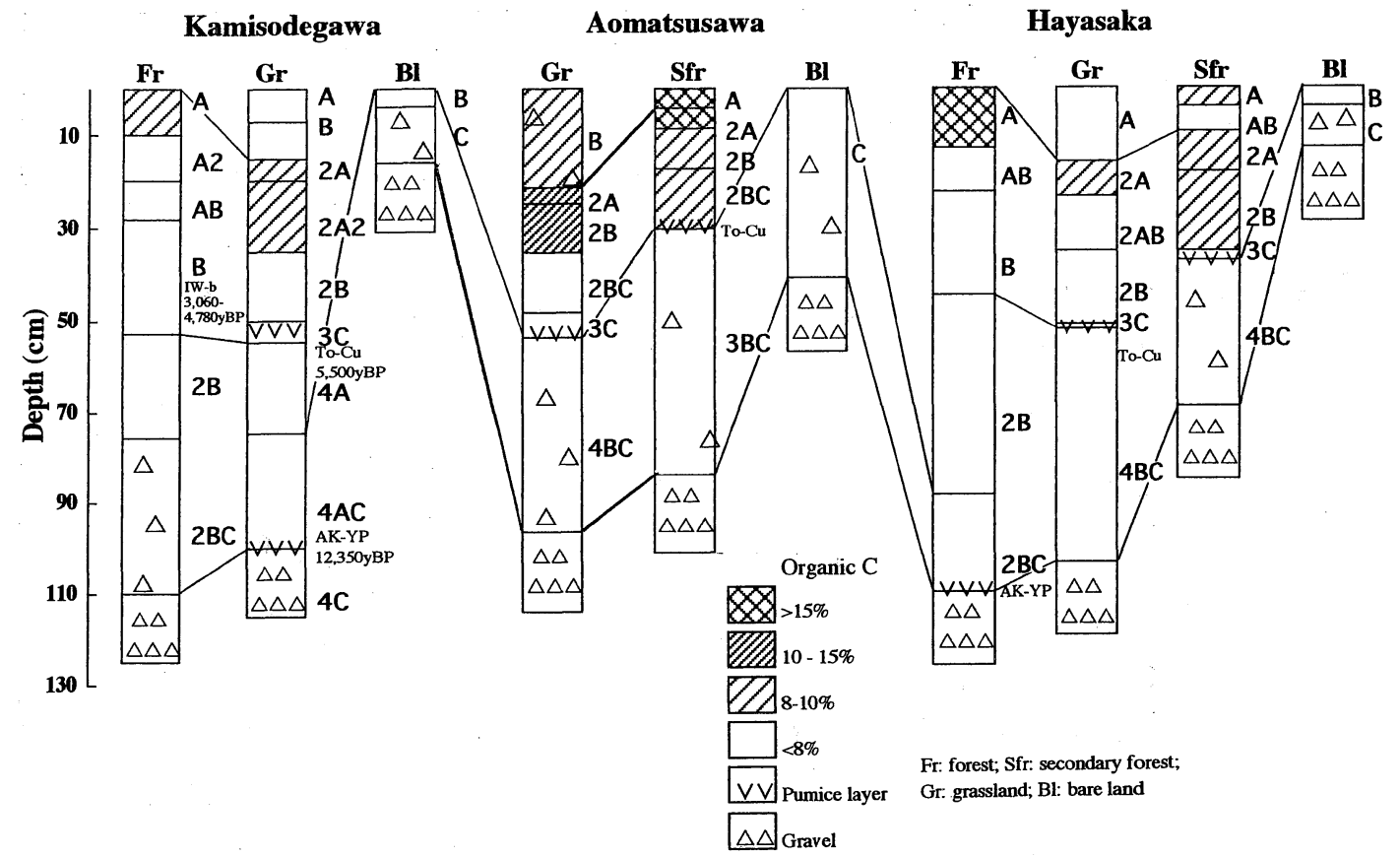

Fig. 3 Schematic representation of pedons from Kamisodegawa, Aomatsusawa and Hayasaka areas 


\section{Morphological properties}

The horizons were described according to standard procedures (Soil Survey Staff, 1992) and particle-size distribution analysis was carried by the method described by Yoshinaga et al. (1984).

\section{Selected chemical properties}

The $\mathrm{pH}\left(\mathrm{H}_{2} \mathrm{O}\right.$ and $\left.\mathrm{KCl}\right)$ of the soils were determined by adding $25 \mathrm{~mL}$ of deionized water or 1 $\mathrm{M} \mathrm{KCl}$ to $10 \mathrm{~g}$ of soil sample, stirred and the $\mathrm{pH}$ was determined with a glass electrode. To 1.0 $\mathrm{g}$ of soil, $50 \mathrm{~mL}$ of $1 \mathrm{M} \mathrm{NaF}$ was added, the mixture stirred and the $\mathrm{pH}(\mathrm{NaF})$ was read after exactly 2 min. For $\mathrm{Al}_{\mathrm{KCl}}, 10 \mathrm{~g}$ of soil sample was extracted with $100 \mathrm{~mL}$ of $1 \mathrm{M} \mathrm{KCl}$ and the extracts potentiometrically titrated with a standard $\mathrm{NaOH}$ solution using a Hiranuma Reporting titrator. Phosphate retention was determined according to the procedure described by Blakemore et al. (1987). Organic carbon content was determined by Tyurin's method (Kononova, 1961).

\section{Mineralogical properties}

The clay fraction of the samples was treated with dithionite-citrate-bicarbonate (Mehra and Jackson, 1960) and subjected to X-ray analysis in parallel orientation after $\mathrm{Mg}$-saturation and glycerol solvation and $\mathrm{K}$-saturation and heating up to 300 and $550^{\circ} \mathrm{C}$ with a Rigaku X-ray diffractometer RAD-1 A (Fe filtered Co $\mathrm{K} \alpha, 30$ $\mathrm{kV}, 10 \mathrm{~mA}$ ).

\section{Selective dissolution}

\section{a. Acid oxalate dissolution}

The acid oxalate reagent was prepared by mixing $0.2 \mathrm{M}$ ammonium oxalate and $0.2 \mathrm{M}$ oxalic acid in a $4: 3$ ratio, and the $\mathrm{pH}$ adjusted to 3.0 . To $100 \mathrm{mg}$ of air dried clay sample, 200 $\mathrm{mL}$ of the reagent was added and the mixture shaken in the dark for $4 \mathrm{~h}$ at $30^{\circ} \mathrm{C}$. The supernatant was collected by centrifugation.

\section{b. Na Pyrophosphate extractable Al, Fe and $\mathrm{C}$}

To $1 \mathrm{~g}$ of fine earth, $100 \mathrm{~mL}$ of pyrophosphate reagent was added, and the mixture was shaken for $16 \mathrm{~h}$. Four to five drops of $0.4 \%$ Accofloc were added to facilitate flocculation and the mixture was centrifuged.

Pyrophosphate extractable $\mathrm{C}$ was determined by Tyurin's method (Kononova, 1961). For both oxalate and pyrophosphate extrac- tions, the amount of $\mathrm{Fe}$ and $\mathrm{Al}$ were determined by the method described by Davenport (1949) and Si was determined according to the method of Weaver et al. (1968).

\section{5. ${ }^{14} \mathrm{C}$ Dating}

In order to determine the inception of the degradation phenomenon, ${ }^{14} \mathrm{C}$ dating of the buried A horizons of Kamisodegawa and Hayasaka grasslands was made. The humic acids extracted from the soil samples were subjected to ${ }^{14} \mathrm{C}$ dating. The ${ }^{14} \mathrm{C}$ dating was performed at the Gakushuin University in the laboratory of Prof. K. Kigoshi.

\section{Results and discussion}

\section{Morphological properties of soils}

The value and chroma of the undisturbed native forest soils increase with depth and their color range from black at the surface to brown at the bottom of the profile (Table 1).

Apart from showing similar color variation with depth, the grassland and secondary forest soils show in the subsurface a darker layer suggesting the presence of a buried $\mathrm{A}$ horizon. Although the surface soil color of these two vegetation varies according to the degree of organic matter enrichment, they are lighter in color than the buried A horizon. The pedons of bare land, on the other hand, have high value and chroma probably due to the influence of the gravel layer. Thus, the difference in the surface soil color of the pedons is probably due to the deposition of wind-eroded materials from the bare land onto the grassland areas, i.e. before the establishment of trees in the secondary forest. However, in the areas covered with forest, the trees prevented deposition of the wind eroded materials, hence, the buried A horizon is not observed in these areas.

All the soils have fine loam texture, although Aomatsusawa soils show comparatively finer texture than Kamisodegawa and Hayasaka (Table 2). Moreover, Kamisodegawa and Hayasaka show high gravel content in their bottom layers showing that influence of the presence of the bottom gravel layer.

\section{Chemical properties of soils}

The soils show a wide $\mathrm{pH}\left(\mathrm{H}_{2} \mathrm{O}\right)$ range from 4.3 to 6.4. Whereas, the surface soils of the forest profiles of each location have the lowest 
Table 2 Selected physico-chemical properties of the soils of Kamisodegawa, Aomatsusawa and Hayasaka sampling sites

\begin{tabular}{|c|c|c|c|c|c|c|c|c|}
\hline & \multirow{2}{*}{$\frac{{ }^{*} \text { Texture }}{\text { ISSS }}$} & \multirow{2}{*}{$\frac{\# \mathrm{O} . \mathrm{C} .}{\%}$} & \multicolumn{2}{|c|}{$\mathrm{pH}$} & \multirow[t]{2}{*}{${ }^{5} \mathrm{Fe}_{\mathrm{pyr}}$} & \multirow{2}{*}{$\frac{\mathrm{Al}_{\mathrm{pyr}}}{\%}$} & \multirow[t]{2}{*}{$\mathrm{C}_{\mathrm{pyr}}$} & \multirow{2}{*}{$\frac{\mathrm{Al}_{\mathrm{KCl}}}{\mathrm{cmol}(+) / \mathrm{kg}}$} \\
\hline & & & $\mathrm{H}_{2} \mathrm{O}$ & $\mathrm{NaF}$ & & & & \\
\hline \multicolumn{9}{|c|}{ Kamisodegawa } \\
\hline \multicolumn{9}{|c|}{ Forest } \\
\hline A & SCL & 11.5 & 5.0 & 10.9 & 0.64 & 1.18 & 3.72 & 2.87 \\
\hline A2 & $\mathrm{CL}$ & 8.0 & 5.1 & 11.2 & 0.93 & 1.19 & 2.71 & 2.07 \\
\hline $\mathrm{AB}$ & $\mathrm{SiC}$ & 7.8 & 5.5 & 11.6 & 0.71 & 1.29 & 3.14 & 0.59 \\
\hline B & $\mathrm{LiC}$ & 6.2 & 5.6 & 11.5 & 0.47 & 0.98 & 2.15 & 0.36 \\
\hline $2 B$ & $\mathrm{LiC}$ & 5.0 & 5.7 & 11.4 & 0.34 & 0.72 & 1.32 & 0.32 \\
\hline $2 \mathrm{BC}$ & G & 1.4 & 5.7 & 10.7 & 0.13 & 0.30 & 0.38 & 0.39 \\
\hline \multicolumn{9}{|c|}{ Grassland } \\
\hline A & SC & 8.0 & 5.7 & 11.1 & 0.53 & 0.69 & 1.92 & 0.61 \\
\hline B & SCL & 6.1 & 5.7 & 11.4 & 0.39 & 0.69 & 1.59 & 0.39 \\
\hline $2 A$ & $\mathrm{LiC}$ & 15.1 & 5.4 & 10.3 & 0.73 & 1.07 & 4.08 & 0.67 \\
\hline $2 \mathrm{~A} 2$ & $\mathrm{LiC}$ & 10.1 & 5.7 & 11.6 & 0.87 & 1.55 & 4.24 & 0.43 \\
\hline $2 \mathrm{~B}$ & $\mathrm{LiC}$ & 8.3 & 5.9 & 11.7 & 0.74 & 1.27 & 3.71 & 0.32 \\
\hline $3 C$ & $\mathrm{~L}$ & 2.4 & 5.9 & 11.5 & 0.27 & 0.45 & 0.86 & 0.23 \\
\hline $4 \mathrm{~A}$ & $\mathrm{CL}$ & 6.3 & 6.0 & 11.3 & 0.24 & 0.53 & 1.91 & 0.28 \\
\hline $4 \mathrm{AC}$ & $\mathrm{CL}$ & 2.9 & 6.1 & 11.1 & 0.06 & 0.42 & 0.50 & 0.16 \\
\hline $4 \mathrm{C}$ & G & 0.5 & 6.0 & 10.0 & 0.06 & 0.13 & 0.14 & 0.31 \\
\hline \multicolumn{9}{|c|}{ Bare land } \\
\hline B & $\mathrm{SCL} / \mathrm{G}$ & 3.3 & 5.6 & 11.5 & 0.15 & 0.58 & 0.87 & 0.33 \\
\hline $\mathrm{BC}$ & $\mathrm{G}$ & 1.7 & 5.6 & 11.2 & 0.12 & 0.45 & 0.43 & 0.29 \\
\hline \multicolumn{9}{|c|}{ Aomatsusawa } \\
\hline \multicolumn{9}{|c|}{ Grassland } \\
\hline B & $\mathrm{LiC}$ & 8.0 & 5.4 & 11.5 & 0.45 & 1.00 & 1.97 & 0.76 \\
\hline $2 \mathrm{~B}$ & $\mathrm{LiC}$ & 12.3 & 5.2 & 11.7 & 0.84 & 1.77 & 3.61 & 1.26 \\
\hline $2 \mathrm{BC}$ & $\mathrm{LiC}$ & 6.5 & 5.7 & 11.6 & 0.19 & 0.86 & 1.67 & 0.34 \\
\hline $4 \mathrm{BC}$ & $\mathrm{LiC}$ & 3.0 & 5.7 & 11.0 & 0.04 & 0.38 & 0.47 & 0.15 \\
\hline \multicolumn{9}{|c|}{ Secondary forest } \\
\hline A & $\mathrm{LiC}$ & 20.0 & 5.2 & 10.5 & 0.74 & 1.50 & 4.49 & 2.61 \\
\hline $2 \mathrm{~A}$ & $\mathrm{LiC}$ & 16.7 & 5.3 & 10.1 & 1.08 & 1.33 & 3.78 & 2.88 \\
\hline $2 \mathrm{~B}$ & $\mathrm{LiC}$ & 14.4 & 5.8 & 11.3 & 1.17 & 1.66 & 3.28 & 1.53 \\
\hline $2 \mathrm{BC}$ & $\mathrm{LiC}$ & 6.9 & 5.7 & 11.5 & 0.07 & 0.36 & 1.81 & 0.39 \\
\hline $3 \mathrm{BC}$ & $\mathrm{LiC}$ & 2.6 & 6.0 & 11.2 & 0.05 & 0.35 & 0.46 & 0.19 \\
\hline \multicolumn{9}{|c|}{ Bare land } \\
\hline $\mathrm{C}$ & $\mathrm{LiC}$ & 2.2 & 5.6 & 11.2 & 0.05 & 0.38 & 0.46 & 0.16 \\
\hline Hayas & aka & & & & & & & \\
\hline & & & & Fo & & & & \\
\hline A & $\mathrm{CL}$ & 23.1 & 4.3 & 8.0 & 0.66 & 0.76 & 4.33 & 2.88 \\
\hline $\mathrm{AB}$ & CL & 8.4 & 5.1 & 11.3 & 0.53 & 1.28 & 3.76 & 1.68 \\
\hline B & $\mathrm{LiC}$ & 10.1 & 5.4 & 11.8 & 0.76 & 1.61 & 3.86 & 0.62 \\
\hline $2 B$ & $\mathrm{LiC}$ & 5.1 & 5.7 & 11.7 & 0.31 & 1.18 & 1.52 & 0.19 \\
\hline $2 \mathrm{BC}$ & SCL & 1.5 & 5.7 & 11.5 & 0.07 & 0.50 & 0.45 & 0.10 \\
\hline & & & & Gras & and & & & \\
\hline A & $\mathrm{LiC}$ & 7.2 & 5.4 & 11.4 & 0.38 & 0.75 & 2.13 & 0.54 \\
\hline $2 \mathrm{~A}$ & SC & 11.7 & 5.6 & 10.7 & 0.34 & 1.32 & 3.36 & 0.48 \\
\hline $2 \mathrm{AB}$ & $\mathrm{LiC}$ & 7.0 & 6.2 & 11.6 & 0.42 & 1.38 & 2.11 & 0.18 \\
\hline $2 \mathrm{~B}$ & $\mathrm{LiC}$ & 5.2 & 6.3 & 11.8 & 0.64 & 0.87 & 1.81 & 0.24 \\
\hline 4BC & $\mathrm{LiC}$ & 3.8 & 6.4 & 11.3 & 0.17 & 0.51 & 0.68 & 0.30 \\
\hline & & & & econda & $y$ forest & & & \\
\hline A & $\mathrm{LiC}$ & 18.8 & 5.3 & 10.7 & 0.29 & 1.24 & 4.31 & 1.12 \\
\hline$A B$ & CL & 9.1 & 5.3 & 11.5 & 0.44 & 1.05 & 2.66 & 0.82 \\
\hline $2 \mathrm{~A}$ & CL & 10.8 & 5.4 & 11.5 & 0.64 & 1.35 & 3.37 & 0.98 \\
\hline $2 B$ & $\mathrm{LiC}$ & 10.2 & 5.7 & 11.9 & 0.59 & 1.57 & 3.76 & 0.43 \\
\hline $3 \mathrm{C}$ & $\mathrm{LiC}$ & 5.3 & 6.1 & 11.9 & 0.20 & 0.71 & 1.79 & 0.18 \\
\hline $4 \mathrm{BC}$ & $\mathrm{CL} / \mathrm{G}$ & 1.7 & 6.1 & 11.5 & 0.45 & 0.51 & 0.63 & 0.21 \\
\hline & & & & Bare & and & & & \\
\hline B & $\mathrm{LiC}$ & 3.1 & 6.0 & 11.9 & 0.13 & 0.56 & 0.96 & 0.12 \\
\hline $\mathrm{C}$ & SCL/G & 0.7 & 6.1 & 11.0 & 0.25 & 0.31 & 0.38 & 0.18 \\
\hline
\end{tabular}

*SiC: silty clay; LiC: light clay; SC: sandy clay; CL: clay loam; SCL: sandy clay loam; L: loam; G: gravel

'organic carbon; ${ }^{5}$ pyrophosphate extractable $\mathrm{Fe}, \mathrm{Al}$ and $\mathrm{C}$.
$\mathrm{pH}\left(\mathrm{H}_{2} \mathrm{O}\right)$. This shows that $\mathrm{pH}\left(\mathrm{H}_{2} \mathrm{O}\right)$ is related with organic carbon distribution throughout the pedon (Table 2).

The high amounts of bases throughout the profiles and the low amounts of $\mathrm{KCl}$ extractable $\mathrm{Al}$ in the subsoils are reflected in the moderate to slight $\mathrm{pH}\left(\mathrm{H}_{2} \mathrm{O}\right)$, a condition favorable for allophane formation.

Apart from the surface soil of Hayasaka which shows a low $\mathrm{pH}(\mathrm{NaF})$ of 8.0 , all the soils show high values ranging from 10.1 to 11.9 , indicating the presence of high amount of active hydroxy- $\mathrm{Al}(\mathrm{Fe})$ groups in the exchange complexes of the soils. This also indicates the soils are enriched with noncrystalline clay minerals such as allophane, allophane-like constituents and imogolite (Inoue, 1986).

Distribution of organic carbon in the pedons is influenced by vegetation and also the accumulation of wind-eroded materials. As a result, the subsurface soils (buried A horizons) of the grassland and secondary forest have high amounts of organic carbon. Also, there is a positive relation between organic carbon and the distribution of pyrophosphate extractable components ( $\mathrm{Fe}, \mathrm{Al}$ and $\mathrm{C}$ ) throughout the pedon.

\section{Clay mineralogical properties of soils}

The weak peaks on the X-ray diffractograms of clays, as observed in the native forest (undisturbed pedon) soils (Fig. 4), suggest that the soils are dominated by noncrystalline clay minerals, although there might have been some influence of Asian long range eolian dust (source of crystalline clay minerals). The strong peaks at the bottom horizons of Kamisodegawa indicates the presence of crystalline clay minerals. It might be due to the presence of a paleosol of eolian dust accumulation (Inoue and Naruse, 1991) underlying the volcanic ash fall.

The soils of the study areas are allophanic as observed in Table 3 . This result is consistent with the report of Adjadeh and Inoue (1999). The lower content of allophane in the upper layers is probably due to higher contents of humic substances in these layers inhibiting the formation of allophane (Inoue and Huang, 1987). It is also observed that the soils show high Alo $+1 / 2 \mathrm{Feo}(>2.3 \%$ ) (Table 3 ) and apart 
from the humus-rich layers and the bottom layers, most of them have phosphate retention $>85 \%$ and organic $\mathrm{C}<23 \%$, thus meeting the Andic soils requirements (Soil Survey Staff, 1992).

Apart from the bottom horizons in Kamisodegawa, the soils have low bulk densities $\left(0.27-0.62 \mathrm{Mg} \mathrm{m}^{-3}\right)$, suggesting a high content of allophane. It is also consistent

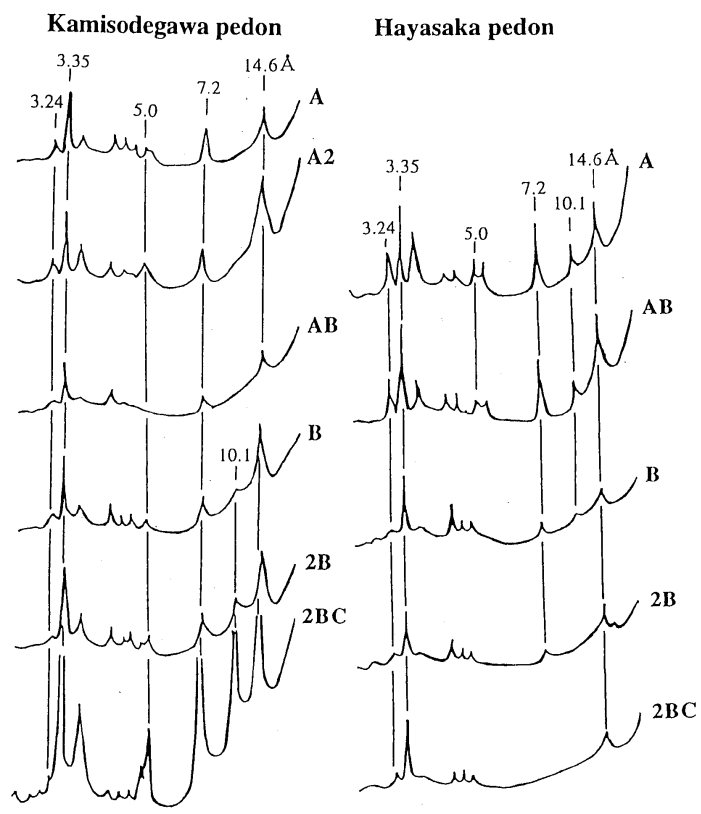

Fig. 4 X-ray diffractograms of air-dried $\mathrm{Mg}$-clay of Kamisodegawa and Hayasaka native forest areas with the report of Maeda and Soma (1986) that bulk density of allophanic Andisols ranges from 0.2 to $0.6 \mathrm{Mg} \mathrm{m}^{-3}$. Shoji et al. (1993) also reported that allophane is one of the most important noncrystalline materials contributing to the low bulk density of Andisols through the development of porous soil structure.

The native forest soils of the study areas have high amounts of allophane and the favorable conditions for the formation of allophanic soils.

\section{4. ${ }^{14} \mathrm{C}$ Dating}

The ${ }^{14} \mathrm{C}$ age of the buried $\mathrm{A}$ horizon of Kamisodegawa is $270 \pm 80$ yrs BP and that of Hayasaka is $100 \pm 70$ yrs BP. These ages coincide with the period of intensive grassland usage in the highland areas and precede the period when degradation of the grasslands started to attract attention in the Meiji era (Kitada, 1985). The ${ }^{14} \mathrm{C}$ dating also indicates that the Kamisodegawa area started being used (for grassland) before the Hayasaka area.

\section{Mechanism of the degradation in the Kitakami mountains}

The removal of the native forest coupled with the high altitude and severe meteorological regimes on the ridge portion of the Kitakami mountains, make the area a periglacial environment. With the felling of the trees to create the grasslands, a soil that was formerly protected by canopies, becomes vulnerable to the strong winds during winter and heavy rainfall during summer. These erosive

Table 3 Andic properties of the native forest soils

\begin{tabular}{|c|c|c|c|c|c|c|c|c|c|c|c|}
\hline & Feo* & Alo & Alo+0.5Feo & Ox. sol. & Sio & Alo/Sio & Allo & Fehy & $\mathrm{OC}$ & P-ret & Bulk density \\
\hline Samples & & & $\%$ & & & & \multicolumn{4}{|c|}{$\%$} & $\mathrm{Mg} / \mathrm{m} 3$ \\
\hline \multicolumn{12}{|c|}{ Kamisodegawa } \\
\hline A & 6.6 & 1.4 & 4.7 & 35.1 & 1.4 & 1.1 & 6.8 & 11.2 & 11.5 & 84 & 0.49 \\
\hline $\mathrm{A} 2$ & 6.1 & 2.3 & 5.3 & 32.5 & 1.3 & 1.8 & 9.1 & 10.4 & 8.0 & 90 & 0.49 \\
\hline $\mathrm{AB}$ & 6.4 & 8.1 & 11.3 & 60.1 & 5.5 & 1.5 & 32.9 & 10.8 & 7.8 & 97 & 0.44 \\
\hline B & 7.0 & 13.7 & 17.2 & 62.5 & 5.3 & 2.7 & 58.1 & 11.8 & 6.2 & 97 & 0.41 \\
\hline $2 \mathrm{~B}$ & 5.1 & 12.7 & 15.3 & 52.9 & 4.6 & 2.9 & 55.3 & 8.7 & 5.0 & 96 & 0.50 \\
\hline 2BC & 3.5 & 4.0 & 5.7 & 19.8 & 1.3 & 3.1 & 17.4 & 5.9 & 1.4 & 83 & 1.22 \\
\hline \multicolumn{12}{|l|}{ Hayasaka } \\
\hline A & 2.2 & 1.2 & 2.3 & 21.1 & 0.4 & 2.9 & 5.3 & 3.8 & 23.1 & 66 & 0.27 \\
\hline $\mathrm{AB}$ & 2.6 & 2.2 & 3.5 & 36.0 & 0.8 & 2.7 & 9.2 & 4.4 & 8.4 & 91 & 0.42 \\
\hline B & 2.6 & 5.5 & 6.8 & 62.9 & 4.2 & 1.4 & 25.0 & 4.4 & 10.1 & 97 & 0.34 \\
\hline $2 B$ & 3.1 & 7.7 & 9.2 & 70.8 & 6.8 & 1.2 & 37.6 & 5.3 & 5.1 & 97 & 0.45 \\
\hline 2BC & 2.0 & 7.1 & 8.1 & 72.0 & 6.9 & 1.1 & 34.3 & 3.5 & 1.5 & 97 & 0.62 \\
\hline
\end{tabular}

* Feo, Alo, Sio: acid oxalate extractable $\mathrm{Fe}, \mathrm{Al}$ and $\mathrm{Si}$; $\mathrm{Ox}$. sol.: acid oxalate soluble components

Allo: allophane according to Parfitt (1990); Fehy: ferrihydrite (Fehy= Feo x 1.7) 
processes are further enhanced by the repeated freezing and thawing cycles of surface soils. The high allophane content of the volcanic ash soils in the study area results in high porosity, contributing to retain large amounts of water resulting in a large water holding capacity (WHC) (Maeda and Soma, 1986) of the soils. The high WHC of the soils of the study area, provides favorable conditions for frost heaving and formation of frost columns. Frost heaving involves upward movement of mineral soils caused by movement of water to the freezing plane and subsequently causing an expansion (French, 1976). During an expansion of a mineral soil, soil aggregates are disrupted as a result of mechanical movements and the root zone is damaged. Once the erosive process starts, even soils with surfaces covered by grass are subjected to the wind erosion. Although the surface soils are held together by the root system of grasses, they collapse due to the removal of the subsurface soils, giving rise to the enlargement of the ruined area (Fig. 5). The presence of buried A horizons is also a sign of the degradation. Its presence is a clear indication of the existence of bare lands in the surroundings.

Figure 6 shows a representation of the degradation mechanism of soils. The felling of the native forest is believed to have triggered a chain of events which caused the denudation phenomenon. After felling of the native forests and creation of grassland, mismanagement such as high livestock density, bad distribution of feeding and watering lots, inappropriate or no application of fertilizers, or mere abandonment of the area, led to subject to wind and water erosions, and eventually formation of the bare lands.

\section{Conclusions}

Through this study it became clear that:

1. Degradation phenomenon of soils observed at the ridge of the Kitakami mountains was triggered by felling of the native forest and mismanagement such as high livestock density, bad distribution of feeding and watering lots and inappropriate or no application of

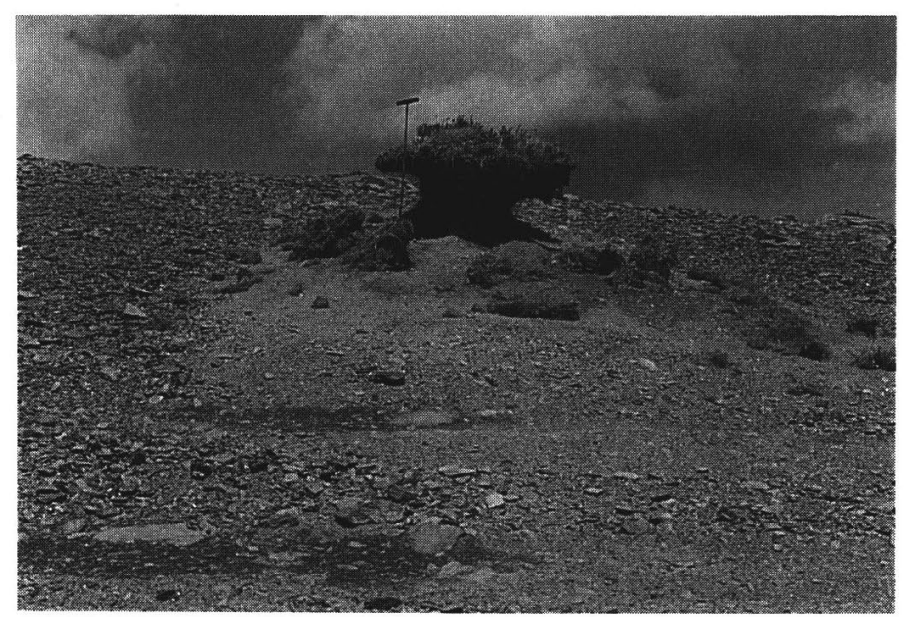

Fig. 5 Completely degraded area showing about 1 meter thick of soil removed by erosion (Kamisodegawa)

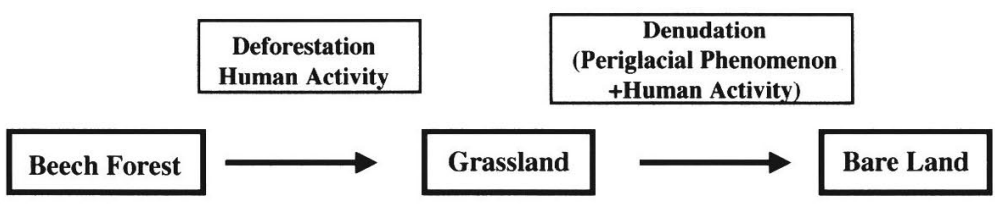

Fig. 6 Proposed mechanism of soil degradation in the Kitakami mountains 
fertilizers, of the grassland areas.

2. The high content of allophane of the soils of the study area show conditions conducive to the erosive processes.

3. Severe environmental conditions prevailing in the mountains such as low temperatures which cause frost heaving and frost columns, strong winds during winter and heavy rainfall during summer are the factors responsible for the soil erosion.

4. On the basis of the ${ }^{14} \mathrm{C}$ ages of buried $\mathrm{A}$ horizon, development of the bare lands started during the transition from the Edo to the Meiji era.

5. Severe environmental conditions of the northern and central portions of the Kitakami mountains became a menace only after human activity had broken the environmental equilibrium that had previously existed.

6. Once an environmental equilibrium is broken, it is difficult to reverse the course of degradation that ensues.

7. Development of the degradation phenomenon in the Kitakami mountains is a result of a chain of events. After the felling of the native forest to create grasslands, the severe environmental conditions coupled with mismanagement, gave rise to the formation of the bare lands.

\section{Acknowledgement}

The authors are very grateful to Prof. Chitoshi Mizota (Iwate University), Prof. Renzo Kondo and Assoc. Prof. Kiyoshi Tsutsuki (Obihiro Univ. of Agric. and Vet. Medicine) for their great help in editing and improving the quality of this work.

\section{References}

Adjadeh, T.A. and Inoue, K. (1999) Morphological, physical and chemical properties of Andisols of the Kitakami mountain range, Japan. Soil Sci. Plant Nutr., 45, 15-36.

Blakemore, L.C., Searle, P.L. and Daly, B.K. (1987) Soil Bureau laboratory methods. A. Methods for chemical analysis of soils. N.Z. Soil Bureau Scientific Report, 80, 44-45.

Brown, L.R. (1981) World population growth, soil erosion and food security. Science, 214, 995-1002.

Davenport, W.H. (1949) Determination of aluminum in presence of iron. Spectrophotometric method using ferron. Anal. Chem., 21, 710-711.
French, H.M. (1976) The periglacial environment. 309 p, Longman Inc., New York.

Higaki, D. (1988) Chronological study of gentle slopes and river terraces in the eastern Kitakami mountains, northeastern Japan. Sci. Reps. Tohoku Univ., 7 th Ser. (Geography), 38, 10-31.

Higaki, D. (1992) History of morphogenetic environments of the Kitakami mountains, Northeastern Japan, in the late Quaternary. Sci. Reps. Tohoku Univ., 7 th Ser. (Geography), 42, 129-162.

Inoue, K. (1980) Stratigraphy, distribution, mineralogy, and geochemistry of late Quaternary tephras erupted from the Akita-Komagatake volcano, northeastern Japan. Soil Sci. Plant Nutr., 26, 43-61.

Inoue, K. (1986) Chemical properties of Ando soils. Wada, K. (ed.) Ando soils in Japan : 69-98, Kyushu Univ. Press.

Inoue, K. and Yoshida, M. (1980) Stratigraphy, distribution, mineralogy, and geochemistry of late Quaternary tephras erupted from the Iwate and AkitaYakeyama volcanoes, northeastern Japan. Soil Sci. Plant Nutr., 26, 149-166.

Inoue, K. and Huang, P.M. (1987) Effect of humic and fulvic acids on the formation of allophane. Schultz, L.G., van Olphen, H. and Mumpton, F.A. (eds.) Proc. of the International Clay Conference : 221-226, The Clay Minerals Society.

Inoue, K. and Naruse, T. (1991) Accumulation of Asian long-range eolian dust in Japan and Korea from the late Pleistocene to the Holocene. Okuda, S., Rapp, A. and Zhang, L. (eds.) LOESS Geomorphological hazards and processes : 25-42, Catena Supplement 20, Catena Verlag.

Iwata, E. (1971) The secondary vegetation in the Kitakami mountains with special reference to the ecological study of grassland species. Gifu Univ. Fac. Agric. Res. Report, 30, 340-376. (J)

Kitada, M. (1985) Pioneer plants in the wind degraded area of the Kitakami mountains. Reforestation Technology, 11, 8-15. (J)

Koaze, T. and Sawaguchi, S. (1988) The glacial scenery imitated by human-ruined bare land in the Kitakami mountains. Kagaku, 58, 548-556. (J)

Kononova, M.M. (1961) Soil organic matter. Its nature, its role in soil formation and in soil fertility : $450 \mathrm{p}$, Pergamon Press, Oxford.

Lal, R. and Stewart, B. A. (1992) Need for land restoration. Soil restoration. Adv. Soil Sci., 17, 1-11.

Machida, H. (1987) Volcano, tephra and giant collapse. Japan Assoc. for Quat. Res. (ed.) Explanatory text for Quaternary maps of Japan : 11-16, Univ. Tokyo Press.

Maeda, T. and Soma, K. (1986) Physical Properties. Wada, K. (ed.) Ando soils in Japan : 99-111, Kyushu Univ. Press.

Mehra, O.P. and Jackson, M.L. (1960) Iron oxide removal from soils and clays by a dithionite-citrate system buffered with sodium bicarbonate. Clays Clay Miner., 5, 317-327. 
Onodera, H. (1963) Deformed coniferous trees in the southern part of the Ohu mountain. Ann. Tohoku Geogr. Assoc., 15, 112-119.

Parfitt, R.L. (1990) Allophane in New Zealand-a review. A ust. J. Soil Res., 28, 343-360.

Shoji, S. and Otowa, M. (1988) Distribution and significance of Andisols in Japan. Kinloch, D.I., Shoji, S., Beinroth, F.H. and Eswaran, H. (eds.) Proc. International Soil Classification Workshop, Japan : 13-24, Japanese committee for 9 th Int. Soil Classification Workshop, for soil management support services, Washington, DC, USA.

Shoji, S., Nanzyo, M. and Dahlgren, R.A. (1993) Volcanic ash soils : Genesis, properties and utilization. 288 p, Elsevier.

Soil Survey Staff (1992) Keys to soil taxonomy. 5 th ed. 541 p, AID, USDA-SMSS Technical Monograph No. 19, Blacksburg, VA.
Suiri Kagaku Kenkyujo (1996) Report on the current circumstances of the presence of a bare land formed by erosion in the Kitakami mountains and its restoration. 120 p, Iwaizumi Government Forest Bureau. (J) Suzuki, H. (1966) Distribution of freeze-thaw days in Japan. Geog. Rev. Japan, 39, 267-270. (J+E)

Takahashi, K. (1976) Report of the development of large scale agriculture in Kitakami, north Iwate. Forestry agency, 1-47. (J)

Weaver, R.M., Syers, J.K. and Jackson, M.L. (1968) Determination of silica in citrate-bicarbonatedithionite extracts of soils. Proc. Soil Sci. Soc. Am., 32, 497-501.

Yoshinaga, S., Egashira, K. and Nakai, M. (1984) Method of particle size distribution analysis for Ando soils. Jpn. J. Soil Sci. Plant Nutr., 55, 248-256. (J)

$(\mathrm{J}+\mathrm{E})$ in Japanese with English abstract, $(\mathrm{J})$ in Japanese.

\title{
北上山地における人為的土壤荒廃
}

\author{
高地セリア好美*1 ・井上 克 弘*2
}

北上山地尾根沿いには, 約 350 ha に及ぶ風食荒廃地 が存在しており, 特に, 風上である西向き斜面に多く見 られる. 風食荒廃地周辺の表層は, 角磁層上に更新世の 秋田-駒ヶ岳起源の秋田-駒ヶ岳-g と柳沢浮石, そして 完新世の十和田火山起源の中掫浮石と岩手山起源の岩手 -b の各テフラを母材とする土塨の累積層からなり, 草 地・二次林域ではこれを風積土層が覆う. 当地域はかつ て天然ブナ (Fagus crenata) 林に被われていたが，馬や 牛の飼育のために皆伐され, それが土鏆荒廃の引き金と なったと思われる. その後, 不十分な管理もしくは放置
により, 森林の保護を失った土壌は氷河期的な厳しい環 境にさらされて, 凍結, 融解を繰り返し, 風食と雨滴浸 食により土壤荒廃が進んだ. 調査地域の土壌はアロフェ ン質であり, その土壌特性は浸食を著しく促進させた. 埋没 $\mathrm{A}$ 層の ${ }^{14} \mathrm{C}$ 年代值によると, 土壤荒廃は江戸時代

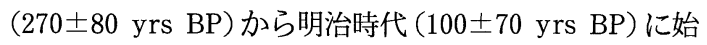
まったと推定される. 厳しい環境下における森林伐採後 の不適切な管理が, 荒廃を進ませたのである. 北上山地 における土壌荒廃は, 厳しい気候, 土袞特性, そして人 為的活動の相互作用の結果である.

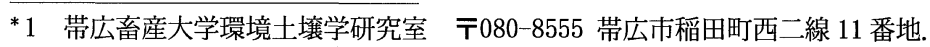

*2 岩手大学農学部 T020-8550 盛岡市上田 3-18-8 (1998 年 8 月 16 日逝去). 